\title{
Luanda and Maputo: Accounts of the Two Capitals in Urban Heritage Discourse
}

\author{
WALTER ROSSA
}

Universidade de Coimbra

\begin{abstract}
From the perspective of urban studies, this article provides an account of the evolution and heritages of Luanda and Maputo. Drawing on notions of capitalness and heritages of Portuguese influence, the article argues for a reconciliation with the legacies of material culture and their intergration into the daily imaginary of post-independence Mozambique and Angola
\end{abstract}

Keywords: Angola; Mozambique; Urban studies; Colonial architecture; Heritages of Portuguese influence

The Portuguese colonial system developed Luanda and Maputo as heads of territories at different times and in different ways. ${ }^{1}$ What exactly does this mean? In fact, they functioned as capitals at several levels over the course of their existence. First, they were capitals of processes of external economic exploitation, such as the slave traffic to the Americas or the mines of the Transvaal. They then became capitals of colonial territories whose recognition, conquest, delimitation, and exploitation they headed. Later, they evolved into

\footnotetext{
${ }^{1}$ This article results from the project "De S. Paulo de Luanda a Luuanda, de Lourenço Marques a Maputo: capitais coloniais em tempos pós-coloniais" (PTDC/CLELLI/122229/2010 - FCOMP-01- 0124-FEDER- 019830), which was financed by Fundos FEDER through the Programa Operacional Factores de Competitividade and by the Fundação para a Ciência e a Tecnologia.
} 
nodes of resistance, centers of struggle for the self-determination of colonized peoples. After independence, they operated as foci of domination in the context of civil wars, as well as sanctuaries for those forced to abandon their worldly goods and flee from their homes. Finally, they were both capitals involved in peace processes, reconciliation, and a search for national prosperity, security, and stability.

As a result, the existence of many varied accounts of these cities is inevitable. They include stories of war and peace, prosperity and misery, oppression and resistance, of perseverance, disappointment, and utopia. There are stories that offer details from which we embellish a specific imaginary constructed around each city's idiosyncrasies. These imaginaries are always scattered and confused, because the temporal horizons, images, and narratives that form it are numerous, with many direct personal experiences entwined. The individual stories that contribute to a collective sense of nationhood unconsciously feed into national symbols and are often more resilient than a coat of arms, an anthem, or a flag.

In the face of so many written stories about and from Luanda and Maputo, what can these cities' territorial and urban materiality tell us from the perspectives of their heritages and of sustainable development? One way to answer this question would be to consider the various extant accounts of the evolution of both cities (Amaral; Martins; Mendes; Morais). There is, however, another way to tackle the question by reflecting on and attempting to clarify the meanings that the histories of Maputo and Luanda embody, albeit ambivalently, in the present imaginaries of their respective nations. In the present essay, I adopt the latter approach in an attempt to reconcile the cities' current residents with their own heritages. Through their resilience, these heritages have the potential for an integrated and thus sustainable form of development.

\section{Capitalness, symbolism, and utopia}

During its five centuries of existence, the Portuguese colonial system fostered the establishment of various territorial settlements. As Charles Boxer observes, Portugal was a seaborne empire and, whenever a new territory was encroached upon, urban trading posts would arise along the coast, in the vast majority of cases adjoining native settlements, since those had generally been established in the best locations. Thus, they were ex novo rather than ex nihilo foundations, as 
traditional historiography would have us believe. The site had to offer, at least, a good port and defenses, access to the hinterland and replenishment of supplies. They were port-cities that, from the perspective of those establishing them, demarcated territories and proclaimed intentions of sovereignty. They were bridgeheads for projects developed in Lisbon. From formal and institutional points of view, they were designed essentially as extensions of Portuguese port cities. In cases for which the Portuguese colonizers had greater expectations, Lisbon was the model, even in the regulation of municipalities. Such cases include Goa, Salvador da Bahia, and Luanda; more recent examples can be found in cities such as Rio de Janeiro, Dili, Lourenço Marques, Panaji, and Ribeira Grande de Santiago (Cabo Verde).

The success of these urban processes was dependent on territorial developments, some of which were projects of conquest. Sometimes the process took centuries, as was the case of Luanda. In general, urban establishments developed along the coast and only to a much lesser extent in the hinterland, which was often enough settled along rivers and later along railway lines built through valleys. That is, coastal urban networks were first established before pushing inland to regions that, in turn, acquired their own hierarchy. This was how, after starting out as a foothold, the coastal city evolved into an interface between the seaborne Portuguese colonial system and the territory it governed.

Since different projects of colonial hegemony confronted Portuguese imperial designs, the territory structured by the urban network and captained by a port city had to be recognized, designed, delimited, and defended. The initial port city finally became a capital or, driven by the dynamics generated by the territorial definition of the hinterland or by new port requirements, lost its status to rival locations. Examples of this switch include the pairs Salvador da Bahia/Rio de Janeiro; Lifau/Dili; Ribeira Grande/Praia; and Ilha de Moçambique/Lourenço Marques. All are coastal cities, but only the latter in each pairing provides deep-sea harbors capable of receiving deep draught ships, a common feature in the implantation of the capitals of the Portuguese colonial system. Indeed, it was only four centuries after the foundation of its colonial capitals along the coast, and a century-and-a-half following independence, that Brazil created Brasília and shifted its seat of political power inland.

Replicating Lisbon, the major city-ports were almost invariably the entry and exit points of the colonial territories and served to concentrate their political, 
military, and administrative importance while boosting both their economic activities and their cultural development. They became hotbeds of cosmopolitanism. The symbolism they naturally appeared to embody derived from the territory they nominally governed. Initially, that symbolism was steeped in replications of Portugal before taking a more independent route. There were, of course, always areas of the city that were hidden or not shown, that did not count for the construction of the image and, ultimately, for the symbolism of the territory's capital. This becomes apparent in the segregated use of symbols, as if the city were only the white-populated areas built up with asphalt and concrete. The colonial system invested strongly and consciously in portraying itself as something transported from Lisbon by sea-sometimes even literally, by putting statues, bas-reliefs, imperial stone crosses, and urban decorative and functional items on public display that were identical to those found in Lisbon.

From the 1940s onward, there was a deliberate trend towards monumentality in the cities of Portugal's African colonies, and most conspicuously in its capital cities. This trend intersected with the development of an architectural and urban identity that gradually became autonomous. The 1943 Plano de Urbanização da parte marginal da cidade de Luanda by Étienne de Gröer and David Moreira da Silva was one of the first steps in that direction, also marking the onset of the great prosperity that Angola's agrarian economy experienced in the immediate aftermath of the Second World War. The space of representation that it rhetorically proposed as the "Praça do Império," which eventually became known as the Largo de Diogo Cão (now Largo de 17 de Setembro), is a testament to the trend. It was part of a series of investments that gained in momentum with the creation of "development plans" effectively implemented from 1953 onwards. The technical design of these projects underpinned the 1944 creation of the Ministry of the Colonies by Marcelo Caetano, with its Gabinete de Urbanização Colonial that, at first, was entrusted not only with drawing up urban plans but also studies on housing problems in tropical regions and hospital buildings. When the "colónias" reverted to the "ultramar" with the constitutional reform of 1951, this unit was renamed the Gabinete de Urbanização do Ultramar, and it increased in size and duties. It was further strengthened by another reform in 1957 when its name was changed to the Direcção de Serviços de Urbanização e Habitação, a branch of the Direcção Geral de Obras Públicas e Comunicações do Ministério do Ultramar. 
Prolific in both quantity and quality, the Direcção de Serviços de Urbanização e Habitação (DSUH) began to pursue projects building facilities and housing with public investment in the colonies. Notwithstanding some adaptations to the tropical situation, it initially endorsed an architectural language along the lines of the uncompromisingly monumental one the Estado Novo was then refining for its imprint on Portugal. The Largo de 17 de Setembro in Luanda is a good example of this. Nevertheless, throughout the mid 1950s, the effects were felt of the "atualização dos seus profissionais através da frequência de cursos de especialização em instituições estrangeiras" (Milheiro 239), in particular the Architectural Association in London. Taking inspiration from what they had learned abroad, Portuguese architects changed track and some began to research indigenous habitats, seeking to integrate what they discovered into their architectural projects. An example, perhaps extreme, is that of a set of projects for maternity hospitals, where the overall layout reproduces the natives' village structure with isolated cylindrical family houses (cubatas) for each mother, beyond a more conventional surgery and intensive-care block (Bastos). The Estado Novo's official architecture in its colonies thus progressively gained autonomy along with its own forms of expression that reflected more localized concerns and dynamics.

The DSUH remained active until April 1974. The stimulation and redefinition of urban landscapes it promoted generated the various synergies. From the 1960s onwards, the main municipalities, starting with Luanda and Maputo, were granted autonomy to determine their own spatial development. This is a very clear sign of how the impetus given by the development plans catalyzed the emergence of local technical capacity. In the private sector, the considerable increase in projects awarded to Portuguese architects encouraged many to migrate to the colonies. The demand for architects in the colonies exceeded anything hitherto experienced in Portugal. Furthermore, architects had a creative freedom in Africa that allowed for measured experimentation. The cosmopolitanism characteristic of Luanda and Maputo signified a territorial renewal and inspired the entire colonial system, from state institutions to private speculators. In Portuguese African colonial cities, architects and urban planners could venture beyond the limited and dated tastes restricting many of their colleagues in Portugal. 
The aftermath of World War II brought about a new international order that demanded decolonization. Portugal tried to ignore this trend and mounted an increasingly virulent defense of its empire. It developed a theoretical and rhetorical apparatus to justify its continued possession of colonies, while drawing up unusually strong urban stimulus policies. To set these policies in context, it is worth pointing out that the architectural Modern Movement in countries like Ghana, Senegal, Kenya, Zambia and Ivory Coast integrated a spirit of national independence (Hers; Kultermann, New Architecture and World Architecture), while South Africa's and Portugal's colonies still nurtured a vision of white utopia (Haarhoff). Put another way, modern expression in architecture and urbanism, with its utopian push to build ex novo a more just and prosperous society, became in the Portuguese case a central element in the urban discourse of racial segregation (Njoh). The common denominator for both Portugal and South Africa is the instrumentalization of architecture and urban development as rhetorical devices in the expression of power.

In Luanda and Maputo, the modern white utopia was inscribed in several major real estate investments made by colonialists, investments that increased significantly during Angola and Mozambique's wars for independence. The imagined white utopia can be seen in numerous highly sophisticated residences and in Luanda and Maputo's best and tallest buildings, some of which had their construction interrupted by independence. It can also be seen in the two capitals' cafés and promenades, parks, leisure complexes, and most notably in their openair cinemas (Tostões). The cities appeared to be an incredible new urban world for those who arrived from a depressed metropolis. In retrospect, however, they were part of a clearly flawed utopian tale. They could not work precisely because they did not represent who and what was actually there. The built utopia symbolized nothing for an overwhelming majority of the population. It foundered by not integrating the Other; instead, it was constructed on the Other's back.

The new urbanism developed in the Portuguese African colonies from the 1950 s to the 1970s and, particularly, in their capitals, effectively created dual cities. It inscribed society onto the territory. That is, despite the absolute interdependence between the concrete city and the musseque or caniço (terms for hut neighborhoods or shantytowns in Angola and Mozambique, respectively) and the improvements that, in spite of everything, the colonial state also made to the latter, only the zones consonant with the vision of modern utopia were recognized 
as "city." Only they contributed to colonial imagery and symbolism. This segregated situation, embodied in the cityscape, challenged the postindependence nations in a way that the Angolan and Mozambican states have yet to tackle comprehensively (Melo; Rossa, "A fénix do património colonial"; Vanin; Viegas). In both Luanda and Maputo, the legacy of the segregated city continues in paved areas where social classes do not always come from diverse backgrounds. In other words, the cities' traditional divisions - both geographical and social-persist in different ways to this day.

Sooner or later, such social disparity was bound to explode. This is what occurred in 1975, and the consequences of that explosion will take time to resolve. This is quite normal. We only need to remember the length of time it took for the urban networks and cities of the Roman Empire to give birth to the cities and networks of the first European states, such as Portugal. Luanda and Maputo may only need a fraction of the prolonged period we designate as the Middle Ages. Beyond the structural problem of a split wrenching the cities, a duality that is unsustainable in any modern, prosperous, and democratic society, the cities have lost their status as bridgeheads for an imperial system. They have also lost the cosmopolitanism underlying their formation and consolidation. Forced to mature as orphans, they gained the status of absolute capitals and had to adapt to this in governing the construction of their own countries and the structuring of their own societies. Ultimately they needed to create, erect, and develop a new symbolism of autochthonous roots, different from those of the colonial power. In other words, a new utopia was required.

\section{Heritage}

From a Eurocentric angle, what I have so far described is a heritage influenced by the Portuguese. Unsurprisingly, many Portuguese often feel they are represented in the former colonies and that their legacy should be extolled. The way the empire ended tends to conjure up unresolved feelings of loss, further enflamed every time part of its material heritage is destroyed, transformed, or neglected. These residual feelings complicate any assessment of Portugal's cultural/urban legacies as ethics clash with notions of prior ownership.

During the colonial era, the overwhelming majority of native non-settlers in Angola and Mozambique witnessed the creation of an entire heritage that 
deliberately excluded them. Even those who actually built the monuments and buildings rarely benefited from what they constructed. For some, none of this really matters. For others, the buildings are a painful reminder of a past of subjugation they have no wish to recall. There is a smaller group that still identifies with what the buildings represented in colonial times. Any one of these positions merits respect and, likewise, also represents a cultural heritage. Cultural heritage implies recognition. Those who consider something as their cultural heritage must identify with it and have it incorporated within their world with a degree of affect. Ultimately, the non-recognition of the cultural value of Portuguese-influenced heritage by natives is in itself also a colonial legacy and therefore must enter into the equation. What did not disappear during the forty years of independence has been transformed by a great diversity of processes, in an unruly and even anarchic manner. The post-independence years have been difficult because of conflict and profound political and social transitions. For some years now, processes of adaptation have veered towards stabilization and normalization. In their midst, breaking through, calling for attention, are the urban structures, infrastructures, facilities, and buildings bequeathed by colonialism. From an overall perspective, they are not in any way what they were; they could not be nor can they ever return to being what they once were.

Also representing a colonial legacy subsequently boosted by civil wars and unsustainable development are the musseques and caniços, which are now integrated into the cities and contribute to the construction of their symbolism, inclusively as sites of celebration in the struggle for independence. These were informal settlements developed under the conscious indifference of colonial governance, but they are also the outcome of a flight from war and hunger, of a collapse of public assistance, of a non-adaptation of the rural to the urban, and of rigid inequalities. For all these reasons, and in stark contrast to colonial architectural heritage, communities have come to recognize them as part of their identity, as is clearly expressed in national literature. The musseques and caniços that expanded so much after independence are now considered an integral part of the city, with their problems and features, and not as something to be excluded from the equation as the city struggles for sustainable development.

From the point of view of urban and architectural heritage, the Portuguese can take one of two paths in relation to what they left behind in Africa 40 years ago. They can see it as an irreparable cultural loss or they can accept it as 
something with a potential valorization to be explored. The second option is the more sensible and productive. It accepts that today's inhabitants of Luanda and Maputo will only regard what urban studies terms their "built heritage" from colonialism as a legitimate part of their own culture if those physical constructions are fully integrated into contemporary society, and put to new uses (Rossa, Fomos condenados). This is the lesson for any community with a history of consolidated identity and bifurcated sovereignty; this is the lesson that likewise emerges from the formation and development of Portugal from its inception as a nation and at the most critical times in its history. There have always been processes of cultural anthropophagy, which, when successful, ultimately prove to be enriching.

The destruction, transformation, and adaptation of urban and other built assets in which some people still see themselves reflected but which legitimately belong to others who, for reasons related to colonial segregation, do not value the structures in the same way, should be considered quite natural. Those transformations should incite study and be widely discussed so that better policy decisions are made and so that anything that is lost, as well as the process of its demise, can be registered for future memory. Neocolonial forces are often at work in destruction, and this too needs to be noted and these forces challenged.

None of this is possible without reconciling the legacies of material culture and integrating them into the symbolic imaginary of newly independent nations. Implicit in this is a recycling process. In other words, heritage must be considered as something active in a development agenda and not as a straightjacket overloaded with memories in need of exorcism. New urban utopias are needed that do not disown heritages but learn from past mistakes. They will always be utopias, but without them there are no dreams; and without dreams, there are no projects or pathways to a true society.

\section{Works Cited}

Amaral, Ilídio do. Luanda (Estudo de Geografia Urbana). Lisbon: Junta de Investigações do Ultramar, 1968. Print.

Bastos, Cristiana. " "No género de construções cafreais': o hospital-palhota como projecto colonial." Etnográfica 18:1 (2014): 185-208. Print. 
Boxer, Charles. The Portuguese Seaborne Empire, 1415-1825. London: Hutchinson, 1969. Print.

Haarhoff, Errol J. "Appropriating Modernism: Apartheid and the South African Township.” A/Z 1.8 (2011): 184-95. Print.

Hers, Manuel, ed. African Modernism: The Architecture of Independence. Ghana, Senegal, Kenya, Zambia, Côte d'Ivoire. Chicago: U of Chicago P, 2015. Print.

Kultermann, Udo. New Architecture in Africa. New York: Universe, 1963. Print.

-. World Architecture 1900-2000: A Critical Mosaic. Central and Southern Africa. Ed. Kenneth Frampton. New York: Springer, 1999. Print.

Martins, Isabel Maria Nunes da Silva. Luanda, a Cidade e a Arquitectura. Diss. U do Porto, 2000. Print.

Melo, Vanessa. A Produção Recente de Periferias Urbanas Africanas. Discursos, Práticas e Configuração Espacial: Maputo versus Luanda e Joanesburgo. Diss. U de Lisboa, 2015. Print.

Mendes, Maria Clara. Maputo antes da independência: geografia de uma cidade colonial. Lisbon: Instituto de Investigação Científica e Tropical, 1985. Print.

Milheiro, Ana Vaz. Nos trópicos sem Le Corbusier: Arquitetura luso-africana no Estado Novo. Lisbon: Relógio d'Água, 2012. Print.

Morais, João Sousa. Maputo, património da estrutura e forma urbana, topologia do lugar. Lisbon: Horizonte, 2001. Print.

Njoh, Ambe. Planning power: Town Planning and Social Control in Colonial Africa. London: UCL, 2007. Print.

Rossa, Walter. “A fénix do património colonial.” Público 15 Jan. 2015. Print.

- Fomos condenados à cidade: uma década de estudos sobre património urbanístico. Coimbra: U de Coimbra, 2015. Print.

Tostões, Ana, ed. Arquitetura moderna em África: Angola e Moçambique. Lisbon: Fundação para a Ciência e Tecnologia, 2014. Print.

Vanin, Fabio, Maputo, Open City. Investigations on an African Capital. Lisbon: Fundação Serra Henriques, 2013. Print.

Viegas, Sílvia Leiria. Luanda, cidade (im)previsível? Diss. U de Lisboa, 2015. Print. 